\title{
Combined minimally invasive surgical management of a nasal dermoid sinus cyst affecting the frontal sinus: literature review and new classification
}

\author{
Martyna Waniewska-Leczycka, Tomasz Cieslik, Mariola Popko \\ Department of Otorhinolaryngology, Faculty of Medicine and Dentistry, Medical University of Warsaw, Warsaw, Poland
}

Videosurgery Miniinv 2020; 15 (4): 632-644

DOI: https://doi.org/10.5114/wiitm.2020.93327

\begin{abstract}
Introduction: Nasal dermoid sinus cysts (NDSCS) are the most common lesions associated with midline craniofacial anomalies, in the majority of cases diagnosed during childhood. NDSCs affecting the frontal sinus are rare.

Aim: To demonstrate the clinical, radiological and diagnostic pitfalls of NDSCs affecting the frontal sinus.

Material and methods: A retrospective analysis of NDSCS affecting the frontal sinus with a literature review and a novel classification is presented.

Results: We present a rare and complex case of an NDSC in an adult patient that affected the frontal sinus. Endoscopic-assisted open rhinoplasty with endoscopic sinus surgery - Draf type $2 B$ approach - was performed as an effective removal method of choice. A literature review supports our report.

Conclusions: NDSCs affecting the frontal sinus can mimic complications of sinusitis. A minimally invasive combined technique of endoscopic-assisted open rhinoplasty with endoscopic sinus surgery - Draf type $2 B$ frontal sinus approach - is recommended for treatment.
\end{abstract}

Key words: nasal dermoid sinus cyst affecting frontal sinus, frontal sinus, nasal dermoid sinus cyst, nasofrontal dermoid cyst, chronic rhinosinusitis, chronic rhinosinusitis with nasal polyps, aspirin-exacerbated respiratory disease.

\section{Introduction}

Nasal dermoid sinus cysts (NDSCs) are the most common lesions associated with midline craniofacial anomalies and are composed of two embryonic layers, the ectoderm and mesoderm. NDSCs penetrate the space between the nasal dorsum structures with the additional possibility of anterior cranial fossa involvement [1-3]. NDSCs, also known as nasofrontal dermoid sinus cysts or tracts, are benign lesions that belong to a larger group of dermoid cysts capable of developing anywhere in the human body [4, 5]. Dermoid cysts together with epidermoid cysts, pilar cysts, hidrocystoma, and others form a larger group of cysts termed cutaneous cysts (Figure 1) [4, 6, 7]. NDSCs combined with other midline nasal masses (e.g., nasal gliomas, and encephalocele) occur in 1 : 20000 to 40000 live births [2, 4, 8-12]. Moreover, NDSCs represent up to $3 \%$ of changes that occur among dermoid cysts in general and up to $12 \%$ among head and neck dermoid cysts (Figures 2, 3) [1, 3]. NDSCs may contain dermal appendages (e.g., hair follicles, sebaceous glands, and apocrine glands) without endodermal structures (e.g., respiratory epithelium, thyroid tissue or gastrointestinal cells), which distinguish an NDSC from a teratoma $[13,14]$. Although epigenetic changes are the primary cause of NDSC formation, some single familial cases have been reported $[1,8]$.

\section{Address for correspondence}

Martyna Waniewska-Łęczycka MD, Department of Otorhinolaryngology, Faculty of Medicine and Dentistry, Medical University of Warsaw, Czerniakowski Hospital, 19/25 Stepinska St, 00-739 Warsaw, Poland, e-mail: martina.waniewska@gmail.com 


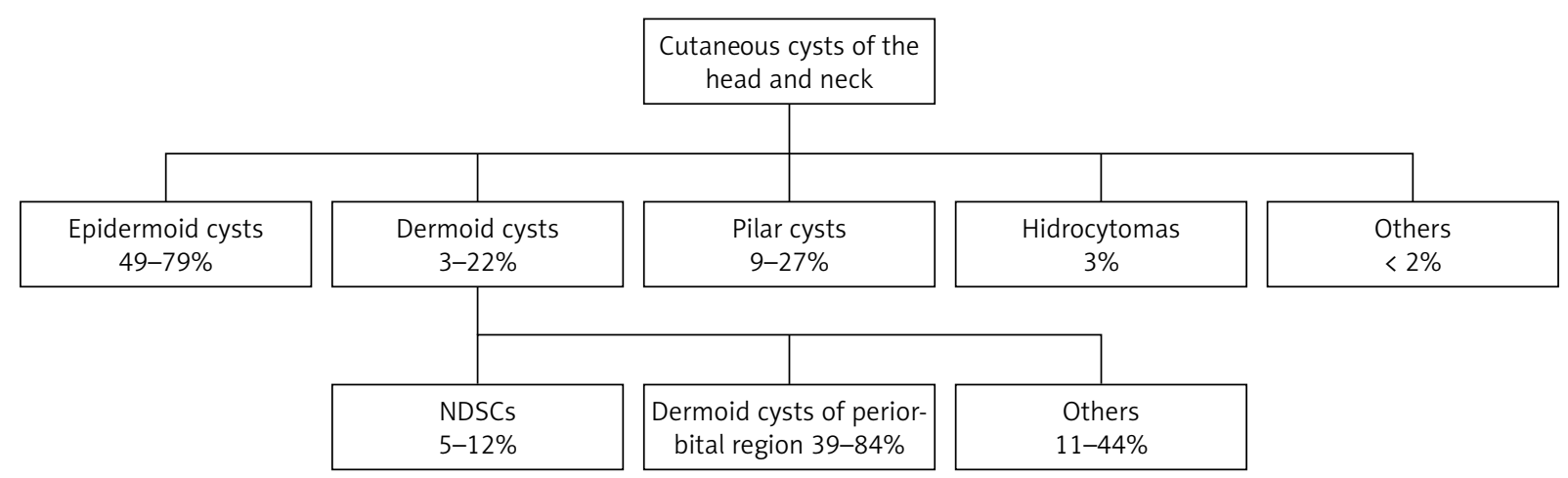

Figure 1. Cutaneous cyst groups $[4-7,23]$

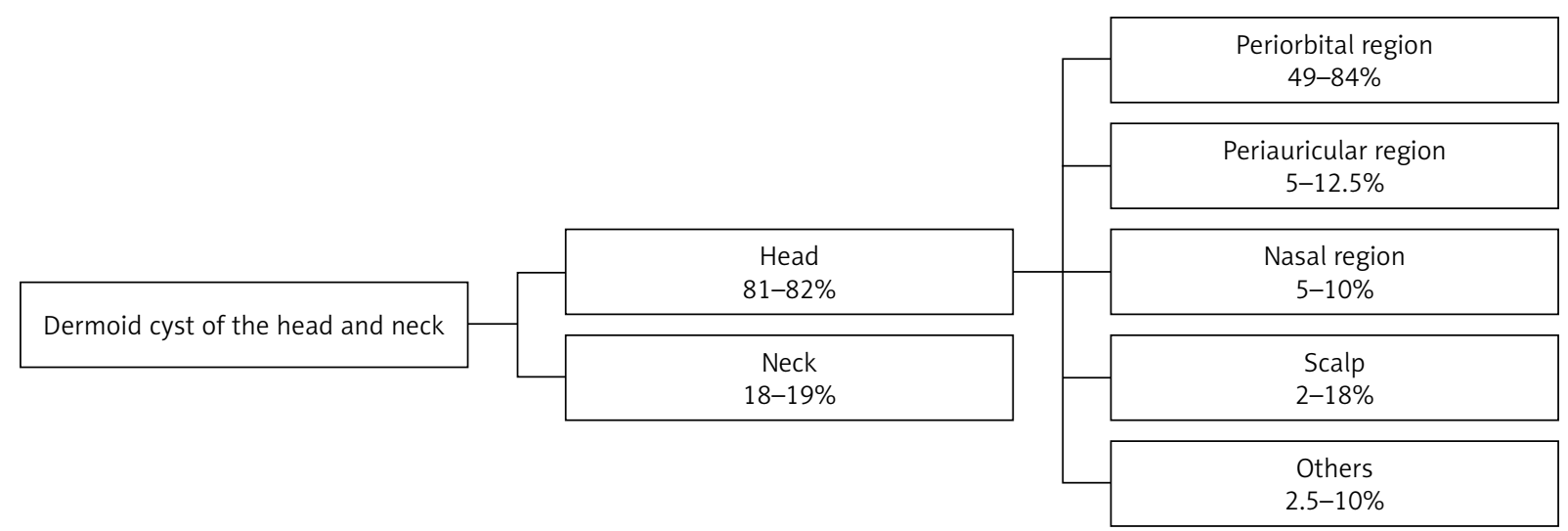

Figure 2. Head and neck dermoid cysts [3, 5, 6, 20, 23]

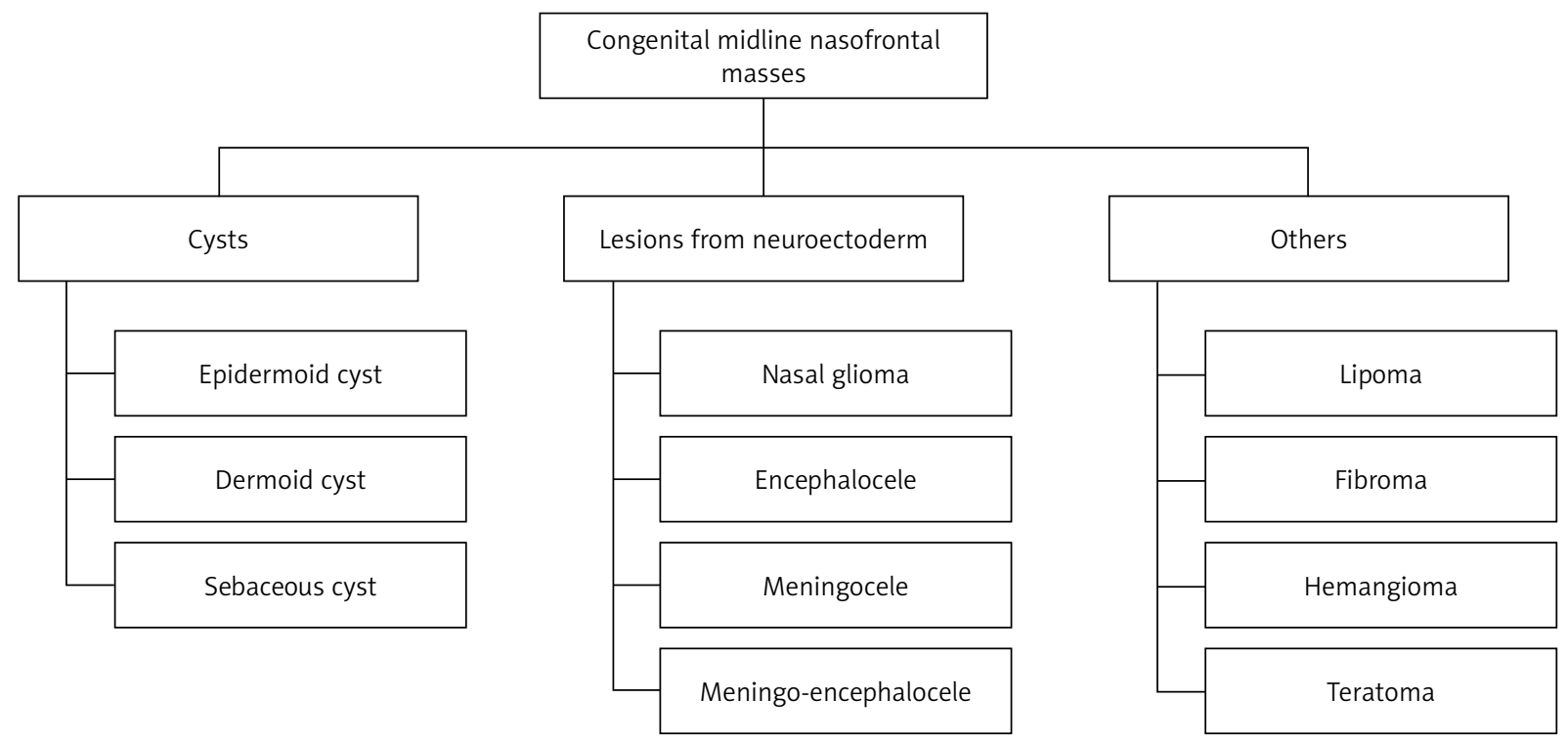

Figure 3. The most common congenital midline nasofrontal masses $[4,26,28,45]$

Intracranial extension of NDSCs is estimated to represent $4 \%$ to $57 \%$ of all diagnosed cases $[10,13]$. The connection of NDSC with the anterior cranial fossa can lead through the foramen caecum, crista galli, and cribriform plate, or can spread directly from the base of the frontal lobe through the lamina 
terminalis or optic chiasma [1]. Most NDSCs have an extra-axial extension only to the attaching dura or cerebral falx; however, in extremely rare cases, there is an intra-axial extension with a direct parenchyma connection [1, 15].

The majority of NDSC cases are diagnosed during childhood between 2 and 3 years of life $[11,16-18]$. This is primarily due to the presence of characteristic signs and symptoms (e.g., external nose deformation or pathognomonic hair concentration protruding from the sinus canal on the skin above the lesion, often accompanied by periodic 'cheesy'-like sebaceous and keratin discharge) [10, $11,13,18]$. NDSCs diagnosed in adulthood are rare, with only two published cases involving the frontal sinus [4, 19-22].

Approximately $39 \%$ to $84 \%$ of head and neck dermoid cysts are located in the periorbital region $[5,6$, $22,23]$, most of which are localized in the superior temporal zygomatico-frontal suture, and about $10 \%$ are localized in the superior nasal frontal suture [24]. NDSCs with an orbital extension are also described in the literature $[22,25]$ and their symptoms include swelling in the periorbital region with deteriorating vision and eye displacement (i.e., proptosis, ptosis or diplopia) [19, 20, 22]. Additionally, since limited forehead or upper eyelid swelling may occur, complications of frontal sinusitis should be taken into consideration during the differential diagnosis, especially when patients do not respond to standard treatment [4, 19-22, 26].

A diagnosis of NDSC is based on a clinical examination accompanied by imaging studies and is finally confirmed with histopathological analysis [2, 12, $24,27]$. The preoperative assessment of the NDSC anatomy and central nervous system involvement using computed tomography (CT) and magnetic resonance imaging $(\mathrm{MRI})$ is crucial for preoperative preparation [2, 4, 10-13, 16, 27]. There are specific features in the imaging results which may suggest an intracranial extension, e.g., enlargement of the foramen caecum or bifid crista galli. However, interpretation in paediatric patients compared to adults can be difficult due to the presence of non-ossified structures $[11,27,28]$. Therefore, the surgeon should always be prepared for situations involving an intracranial extension of the dermoid cyst that may be revealed only intraoperatively, despite the extracranial limitation of the lesion in preoperative imaging studies [12].
Dermoid cysts in the nasofrontal region should be differentiated from other pathologies that can present as a mass, fistula, or sinus with similar manifestations. Figure 3 shows the differential diagnosis of NDSCs, such as encephaloceles, teratomas, sebaceous cysts, and hematomas, from fibrosis, lipomas, and fibromas [2, 3, 10, 20, 28]. Treatment of NDSCs is based on the possibility of surgical excision, which depends on the location, size, and intracranial extension of the lesion $[2,16]$. Complications of untreated NDSCs include spontaneous local infection with frontal bone osteomyelitis, and abscess formation, which can be incorrectly interpreted as a lacrimal sac abscess when medial canthus swelling is present [10, $18,22,29]$. Moreover, long-lasting inflammation can lead to deformations of the nasal bones and cartilage, or even atrophy $[8,13]$. Recurrent local inflammation associated with NDSC that communicate with the central nervous system can be life-threatening and may lead to meningitis or brain abscess $[1,13]$.

Here, we present a case of an adult patient with a NDSC affecting one side of the frontal sinus, who was successfully surgically treated with a combined technique of endoscopic-assisted open rhinoplasty with endoscopic sinus surgery (ESS) - Draf type 2B frontal sinus approach. Additionally, we reviewed the literature on cases of NDSC extending to the frontal sinus in adults and the associated methods of treatment. Furthermore, we propose a new classification for dermoid cysts affecting the frontal sinus.

\section{Aim}

The main aim of this paper is to demonstrate the clinical, radiological and diagnostic pitfalls of NDSCs affecting the frontal sinus and the comparison with the literature.

\section{Material and methods}

Retrospectively collected data was analysed from patient admitted to the Department of Otorhinolaryngology, Faculty of Medicine and Dentistry, Medical University of Warsaw in Poland.

A literature review was performed by a search of the PubMed and Medline database for all relevant English and Polish language studies published from January 1999 to March 2019, using the search terms: "nasal dermoid sinus cyst", "nasal dermoid sinus cyst in adult", "surgical management of nasal dermoid sinus cyst", "dermoid cyst affecting frontal si- 
nus", "dermoid cyst affecting frontal sinus in adult", "nasofrontal dermoid cyst".

\section{Results}

\section{Case presentation}

A 58-year-old man was admitted to the Otorhinolaryngology Department, Faculty of Medicine and Dentistry, Medical University of Warsaw in Poland,

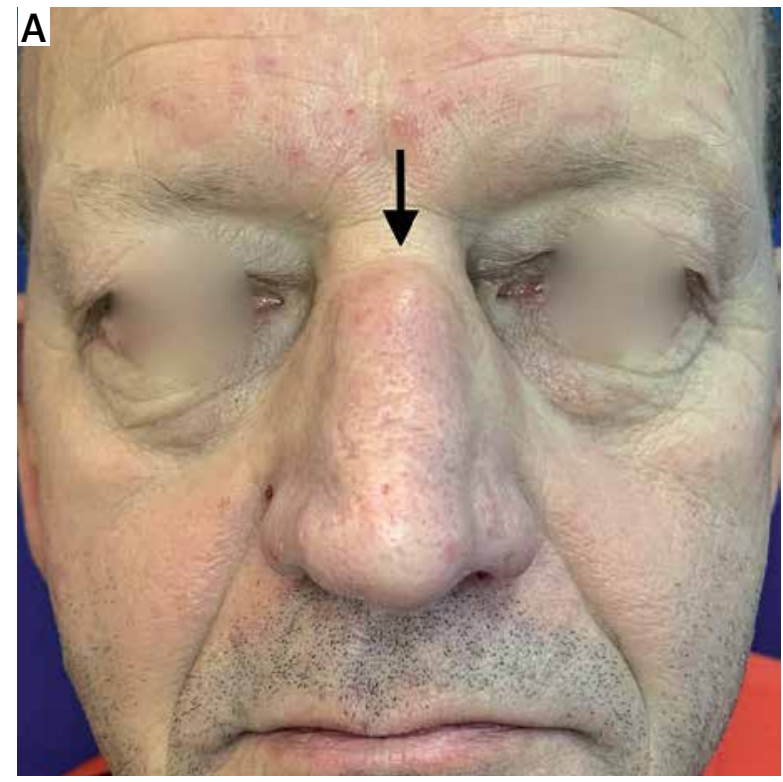

Photo 1. Preoperative pictures of the patient with NDSC involving the external nose. Frontal (A) and lateral (B) view of the external nose demonstrating NDSC located cephalically to the rhinion (arrow)
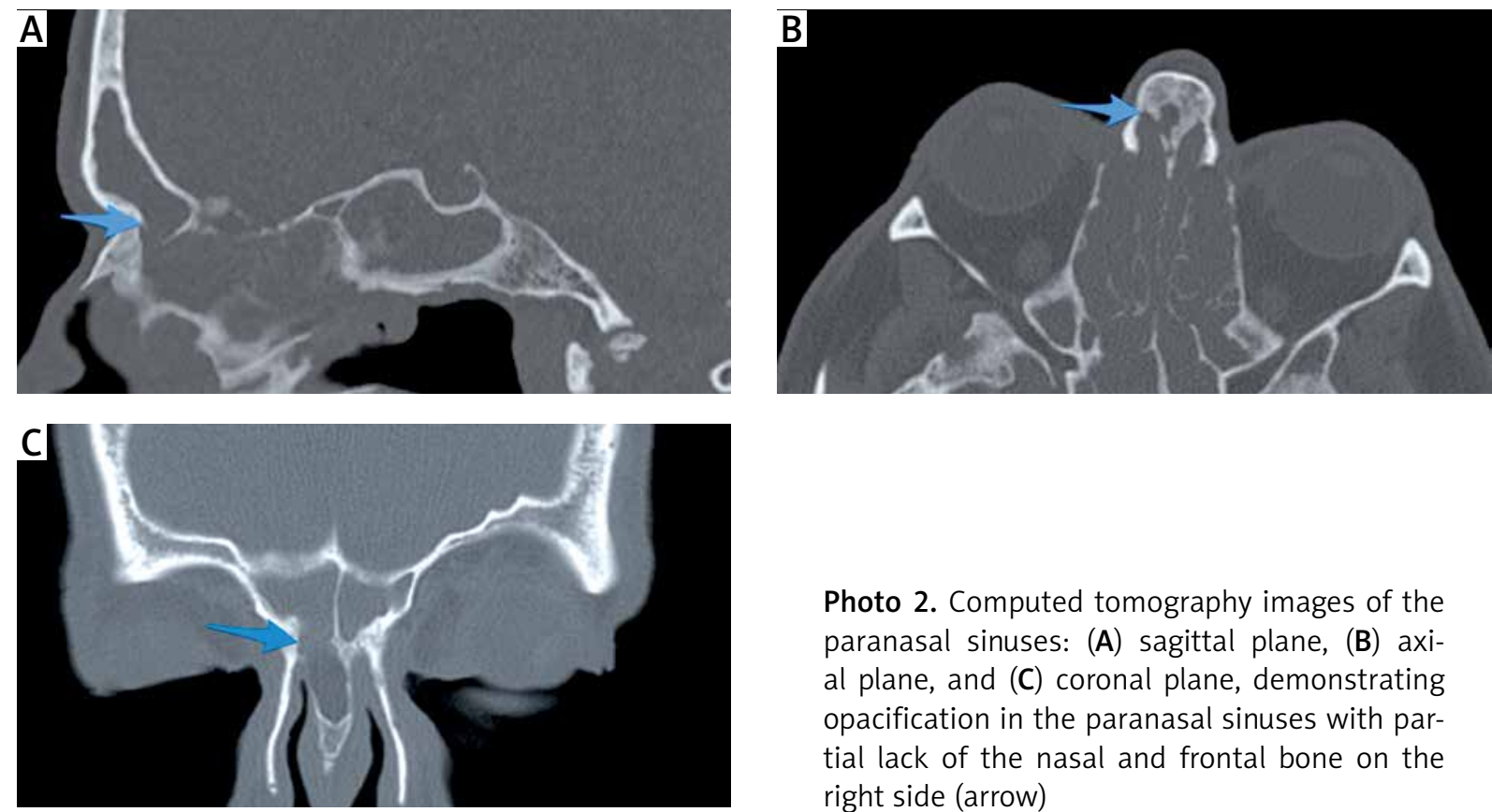

Photo 2. Computed tomography images of the paranasal sinuses: (A) sagittal plane, (B) axial plane, and (C) coronal plane, demonstrating opacification in the paranasal sinuses with partial lack of the nasal and frontal bone on the right side (arrow) 
el and left frontal lobe, complicated by quadriplegia. In 2016, he was successfully treated for Lyme disease and viral meningitis. The patient also underwent several ESS procedures and remained on steroid treatment due to aspirin-exacerbated respiratory disease (AERD) with chronic rhinosinusitis with nasal polyps (CRSwNP). At the beginning of 2018, he underwent an endonasal rhinoplasty due to the nasal dorsum deformity, which reoccurred about a month later.

During hospitalization, CT revealed massive inflammatory changes in the paranasal sinuses (24 points on the Lund-Mackay score) with partial absence of the nasal and frontal bone on the right side (Photo 2). MRI revealed a 27-mm lesion in the nasal dorsum. The density of the lesion was comparable to adipose tissue. The lesion was communicating with
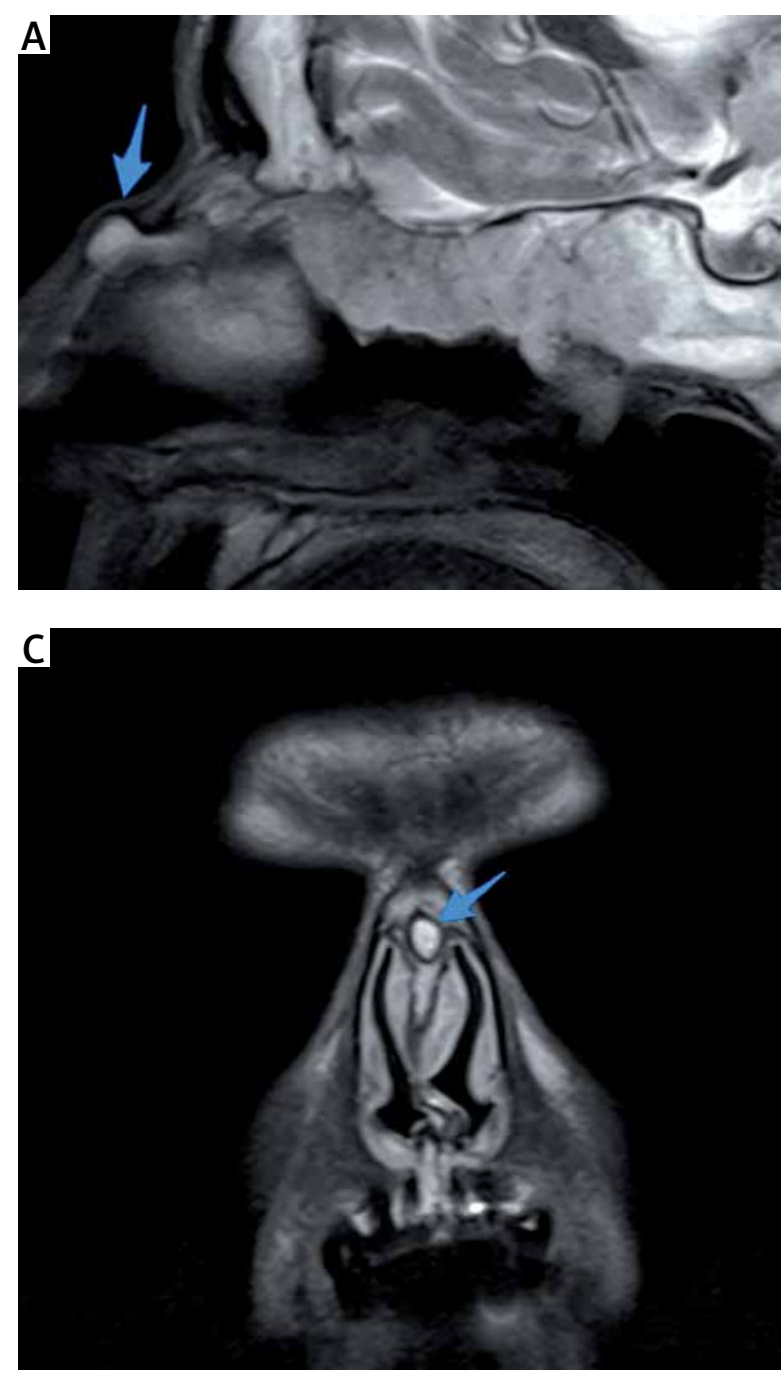

the nasal cavity and frontal sinus without intracranial extension (Photo 3). An endoscopic nasal cavity examination revealed local oedema with polyps and mucous secretion (12 points on the Lund-Kennedy score of endoscopic assessment) [30].

The patient was scheduled for a combined technique of endoscopic-assisted open rhinoplasty with endoscopic sinus surgery (ESS) - Draf type 2B frontal sinus approach. During the first stage of the operation, bilateral sphenofrontoethmoidectomy was performed to remove the polyps and reopen all the inflamed sinuses. During the second stage of the operation, a V-incision for the endoscopic-assisted external rhinoplasty approach was performed. Two additional elliptical incisions were made around the NDSC fistulas. The tract of the fistula was dissected (Photo 4). The main sac of the lesion was filled

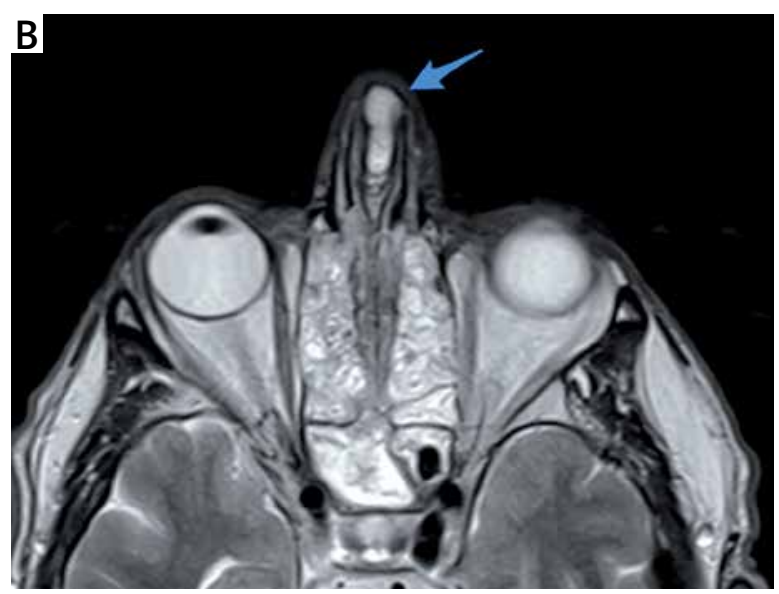

Photo 3. Head magnetic resonance imaging: nasal dorsum lesion communicating with the nasal cavity and frontal sinus without intracranial extension (arrow). (A) Sagittal plane, (B) axial plane, and (C) coronal plane. Note the complete opacification of the paranasal sinuses visible on the axial plane due to the AERD 

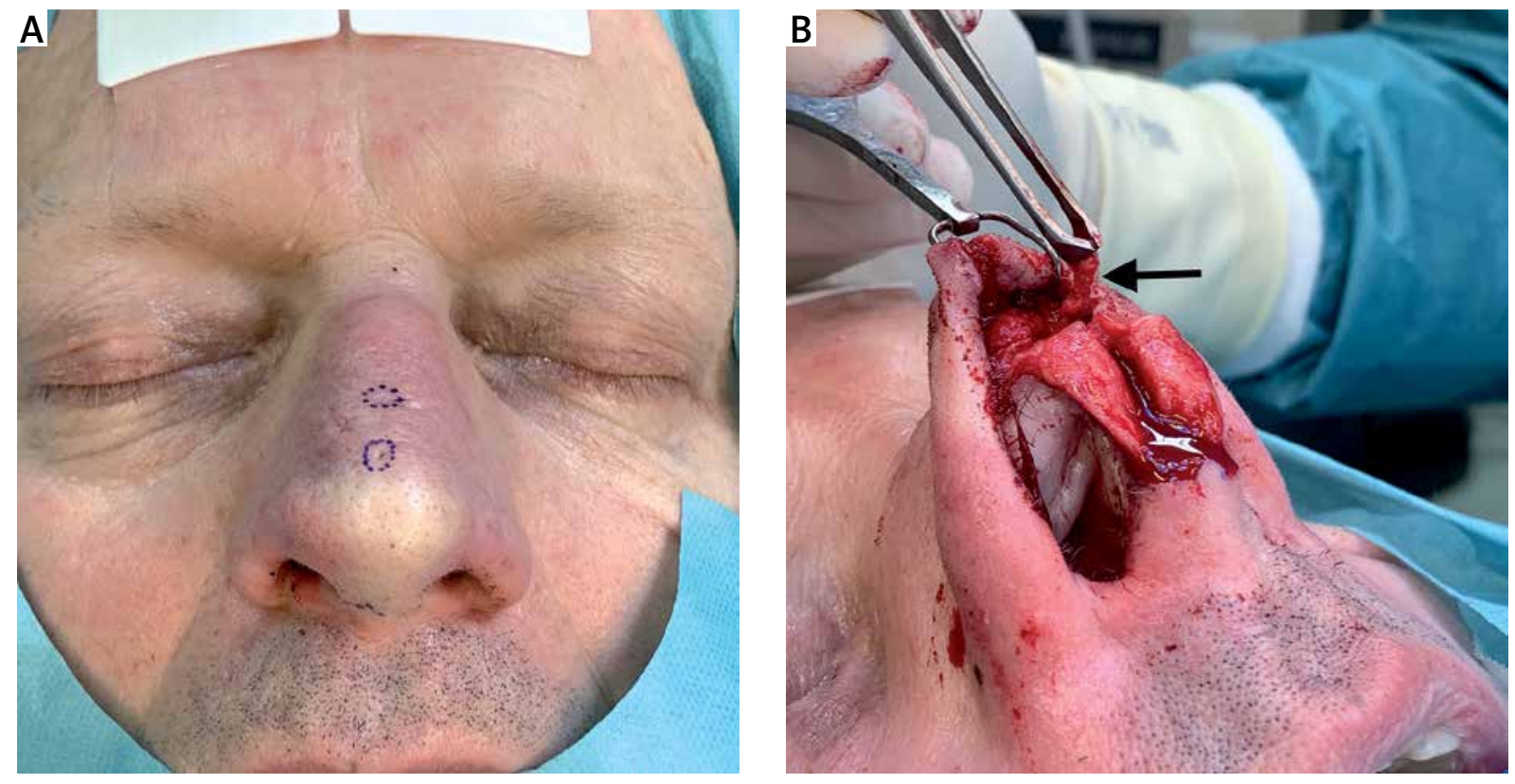

Photo 4. Intraoperative images demonstrating preliminary phase of the combined technique of endoscopic-assisted open rhinoplasty with endoscopic sinus surgery (ESS) - Draf type 2B frontal sinus approach for removal of NDSC. A - Marked elliptical incisions around two fistulas of the NDSC, B - demonstration of the fistula tract of the NDSC (arrow)

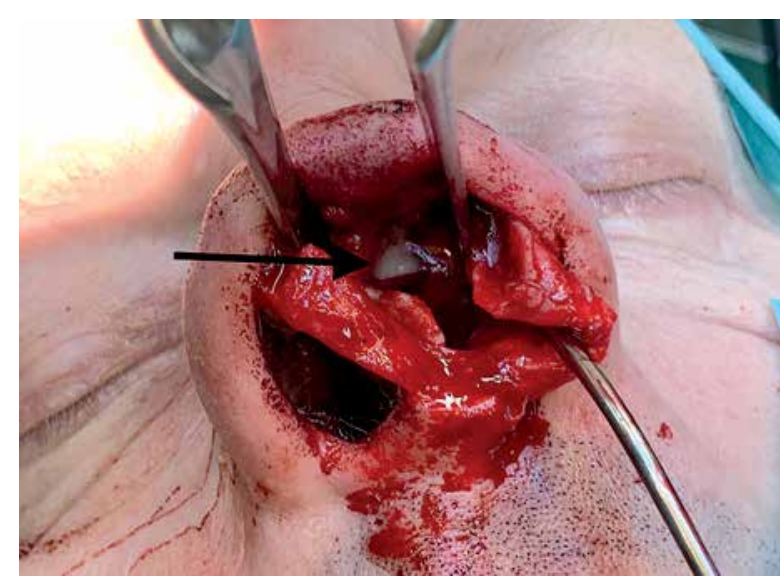

Photo 5. Intraoperative image of the combined technique of endoscopic-assisted open rhinoplasty with endoscopic sinus surgery (ESS) Draf type 2B frontal sinus approach for removal of NDSC. The arrow indicates purulent discharge within the fistula sac

with a 'cheesy'-like sebaceous and keratin substance lined with dermis, including appendages (i.e., hair) (Photos 5, 6).

The lesion extended to the lumen of the frontal sinus (Photo 7). The NDSC was dissected and

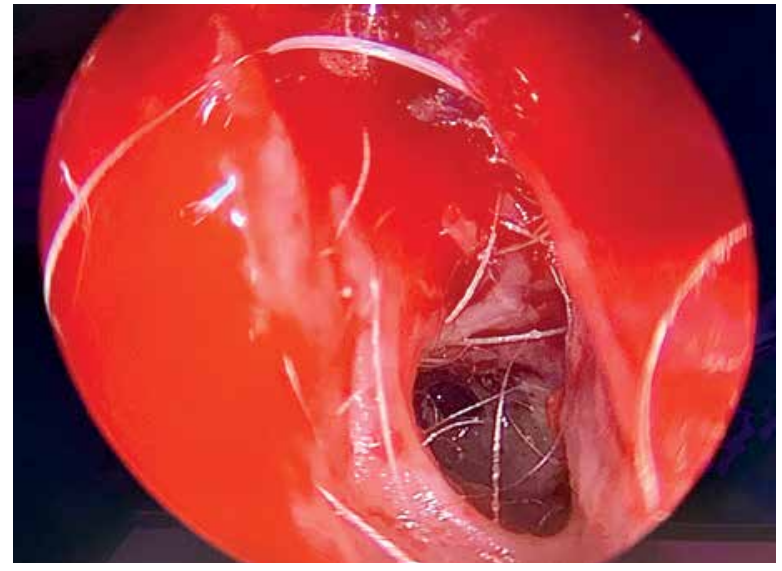

Photo 6. Intraoperative image of the combined technique of endoscopic-assisted open rhinoplasty with endoscopic sinus surgery (ESS) Draf type 2B frontal sinus approach for removal of NDSC. The sac of the lesion filled with a sebaceous and keratin 'cheesy'-like substance lined with dermis, including appendages (hair)

removed completely. The bony surface of the tract was further cleaned using a diamond drill and Draf type 2B frontal recess surgery was performed to extend its ostium. Subsequently, the space after NDSC removal was filled with nasal muscle, adipose tis- 


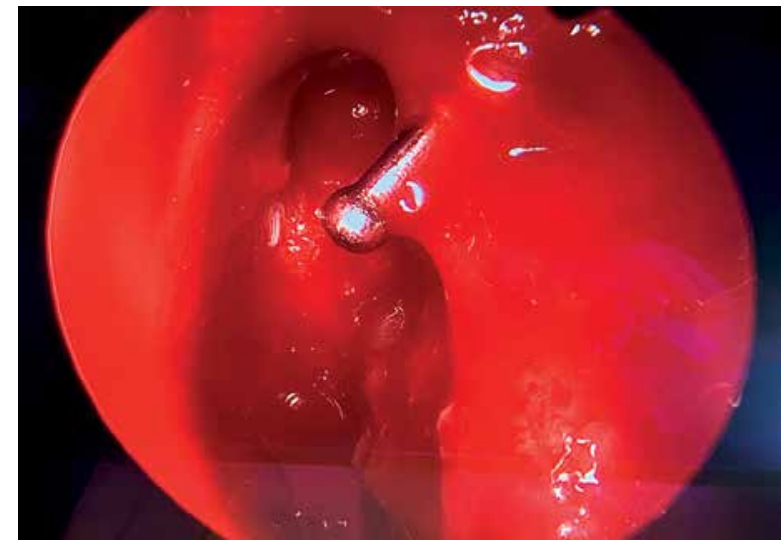

Photo 7. Intraoperative image of the combined technique of endoscopic-assisted open rhinoplasty with endoscopic sinus surgery (ESS) Draf type 2B frontal sinus approach for removal of NDSC. A probe inserted through the rhinoplasty cut shows connection to the frontal sinus recess area

sue of the nasal dorsum, and crushed fragments of nasal septum cartilage. Histopathological analysis confirmed the diagnosis of a dermoid cyst with contained dermoid elements. The patient was symptom free at the 12-month follow-up (Photos 8, 9).

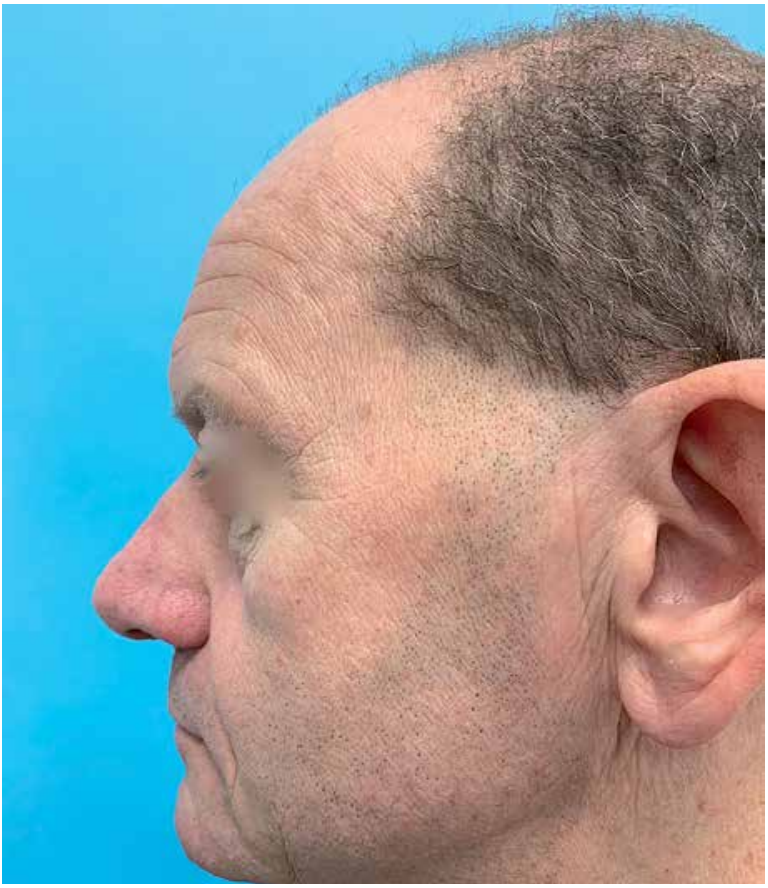

Photo 8. Postoperative image at the 12-month follow-up after excision of the NDSC. The lateral view of the external nose demonstrates no signs of external nose deformation or NDSC recurrence

\section{Literature review}

PubMed and Medline database searching articles from the last 20 years revealed 5 cases of dermoid cysts involving the frontal sinus (Table I).

\section{Discussion}

Here we present: 1) a rare and complex case of NDSC in an adult patient that affected the frontal sinus combined with chronic rhinosinusitis with nasal polyps during the course of AERD; 2) an effective method of surgical treatment with a combined technique of endoscopic-assisted open rhinoplasty with ESS - Draf type 2B frontal sinus approach; 3) a literature review on dermoid cysts affecting the frontal sinus and the available dermoid cyst classifications; and 4) proposal of a new classification for a dermoid cyst affecting the frontal sinus.

NDSCs are typically diagnosed and treated during childhood due to characteristic signs and symptoms. The rarity of this disease in adults has been confirmed in several studies [4, 16, 19-22]. During the past 20 years, only 5 cases of dermoid cysts spreading to the frontal sinus have been published, of which only one was a case of an NDSC affecting the frontal sinus [4], 3 cases were dermoid cysts of the orbit affecting the frontal sinus, and one was an NDSC affecting both the frontal sinus and orbit [22] (Table I). According to the embryological theory of NDSC formation, the cyst can spread to the frontal sinus when the dural diverticulum does not regress during frontal and nasal bone fusion [1, 2, 4, 8, 10, 22].

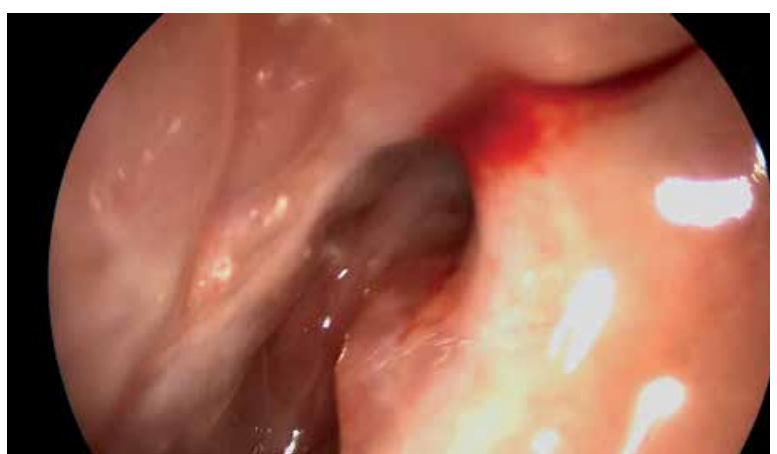

Photo 9. Postoperative endoscopic image demonstrating patent frontal sinus recess with neither pathological discharge nor polyps after combined technique of endoscopic-assisted open rhinoplasty with endoscopic sinus surgery (ESS) - Draf type 2B frontal sinus approach for removal of NDSC at the 12-month follow-up 
Table I. Five previous reports of dermoid cysts involving the frontal sinus in adult patients

\begin{tabular}{|c|c|c|c|c|c|c|c|}
\hline $\begin{array}{l}\text { Reference/ } \\
\text { study }\end{array}$ & Age & Gender & $\begin{array}{l}\text { Dermoid cyst } \\
\text { location }\end{array}$ & $\begin{array}{l}\text { Intracranial } \\
\text { extension }\end{array}$ & Surgical method & Follow-up & Recurrence \\
\hline Post 2005 [4] & 35 & Male & $\begin{array}{l}\text { NDSC affecting } \\
\text { frontal sinus }\end{array}$ & No & $\begin{array}{l}\text { Local skin incision } \\
\text { with excision along } \\
\text { fistula canal. } \\
\text { External approach to } \\
\text { frontal sinus (osteo- } \\
\text { plastic flap) }\end{array}$ & 3 years & None \\
\hline $\begin{array}{l}\text { Pham } 2010 \\
\text { [19] }\end{array}$ & 28 & Male & $\begin{array}{l}\text { Dermoid cyst of } \\
\text { the orbit affecting } \\
\text { frontal sinus }\end{array}$ & No & $\begin{array}{c}\text { External approach } \\
\text { (medial upper-eyelid } \\
\text { incision) }\end{array}$ & No data & No data \\
\hline $\begin{array}{l}\text { Patnaik } 2012 \\
{[21]}\end{array}$ & 50 & Female & $\begin{array}{l}\text { Dermoid cyst of } \\
\text { the orbit affecting } \\
\text { frontal sinus }\end{array}$ & No & $\begin{array}{l}\text { External approach } \\
\quad \text { (unspecified) }\end{array}$ & No data & No data \\
\hline $\begin{array}{l}\text { Gupta } 2012 \\
{[22]}\end{array}$ & 28 & Male & $\begin{array}{l}\text { NDSC affecting } \\
\text { orbit and frontal } \\
\text { sinus }\end{array}$ & $\begin{array}{l}\text { No signs of in- } \\
\text { volvement in MRI, } \\
\text { but with defect of } \\
\text { frontal sinus pos- } \\
\text { terior wall in } \mathrm{CT}\end{array}$ & $\begin{array}{l}\text { Local skin incision } \\
\text { with excision along } \\
\text { fistula canal. Transna- } \\
\text { sal endoscopic skull } \\
\text { base approach to } \\
\text { frontal sinus }\end{array}$ & 8 months & None \\
\hline $\begin{array}{l}\text { Splendiani } \\
2016[20]\end{array}$ & 84 & Female & $\begin{array}{l}\text { Dermoid cyst of } \\
\text { the orbit affecting } \\
\text { frontal sinus }\end{array}$ & Yes & $\begin{array}{l}\text { External approach } \\
\quad \text { (unspecified) }\end{array}$ & No data & No data \\
\hline
\end{tabular}

Furthermore, the lack of childhood cases of NDSC affecting a frontal sinus may be associated with the time of frontal sinus development. The appearance of the frontal sinus begins during the second year of life, although the sinus may not be radiologically observed until the sixth year, and growth continues until the second decade of life [31]. This explains the reported case of a bilateral NDSC causing erosion of the frontal bones imitating a Pott's puffy tumour in a 7-monthold male patient [32]. Since the frontal sinuses had not yet been pneumatized at the time of the diagnosis, frontal sinus involvement may be not possible until adolescence in cases of slower NDSC development [32]. Our presented case affirms this assumption. Additionally, there are cases of NDSCs spreading to other sinuses (i.e., ethmoid cells, maxillary sinus, or sphenoid sinus); however, these cases are extremely rare, with limited data in the literature [3, 23, 33].

Diagnosis of NDSC can be delayed for many years due to the lack of signs of exacerbation [25]. Our patient had all the typical symptoms of an NDSC since childhood; however, a moderate external nose deformity with dorsal exudate was dominated by typical symptoms of CRSwNP during the course of AERD and created conditions for which the correct diagnosis was postponed. To obtain an accurate diagnosis, we performed CT and MRI scans as recommended in the literature. Furthermore, it is extremely important to emphasize that dermoid cysts located in the frontal sinus may mimic CRS complications, which has also been confirmed in previous studies (e.g., Post et al.) $[4,19,22]$.

We present a minimally invasive method for the surgical treatment of an NDSC extending to the frontal sinus. A combined technique of endoscopic-assisted open rhinoplasty with ESS - Draf type 2B frontal sinus approach - was found to be an effective method for NDSC excision. This approach ensured the complete removal of the lesion with perfect vision of the operating field while maintaining the aesthetic effect, and without requiring an external approach to the paranasal sinuses.

The appropriate choice of surgical techniques used to remove NDSCs depends on the size, localization, and intracranial extension of the lesion [2, $4,12,18]$. The rate of recurrence varies from $30 \%$ to $100 \%$ among NDSCs and a complete excision should be always performed, regardless of the chosen technique $[11,17,27]$. Pollock presented the history of methods used for NDSC excision during the early eighties, beginning with the incomplete removal by drainage or a simple incision with minimal aesthetic 
Table II. Surgical methods used to remove NDSCs depending on the lesion extension

\begin{tabular}{|c|c|}
\hline NDSC extension & Recommended surgical methods \\
\hline \multicolumn{2}{|l|}{ Extracranial extension: } \\
\hline Superficial lesions & $\begin{array}{l}\text { - Local excision by direct elliptical incision }[3,23] \\
\text { - Local excision - endoscopic excision [23] } \\
\text { - Open rhinoplasty technique [2] with local excision by direct elliptical incision [40] } \\
\text { - Endoscopic assisted open rhinoplasty technique [9] }\end{array}$ \\
\hline $\begin{array}{l}\text { Intraosseous exten- } \\
\text { sion }\end{array}$ & $\begin{array}{l}\text { - Local excision with intraosseous component bone drilling [3] } \\
\text { - Endoscopic assisted rhinoplasty technique [2,9] } \\
\text { - Transnasal approach [2] }\end{array}$ \\
\hline $\begin{array}{l}\text { Frontal sinus exten- } \\
\text { sion }\end{array}$ & $\begin{array}{l}\text { - Transnasal endoscopic skull base approach with local excision by direct elliptical incision [22] } \\
\text { - External approach (osteoplastic flap) to frontal sinus with local excision [4] } \\
\text { - External approach (medial upper-eyelid incision) [19] }\end{array}$ \\
\hline \multicolumn{2}{|l|}{ Intracranial extension: } \\
\hline Extradural & $\begin{array}{l}\text { - Limited frontonasal osteotomy [3] } \\
\text { - Open rhinoplasty technique [36, 37] } \\
\text { - Endoscopic assisted closed rhinoplasty technique [41] } \\
\text { - Endoscopic assisted open rhinoplasty [2] } \\
\text { - Endonasal O deg. endoscope technique [35] }\end{array}$ \\
\hline Intradural & - Bicoronal flap and frontal craniotomy [2, 3] \\
\hline $\begin{array}{l}\text { Large intracranial } \\
\text { lesions }\end{array}$ & $\begin{array}{l}\text { - Bicoronal flap and frontal craniotomy [2] } \\
\text { - Combined approach - endoscopic assisted bicoronal flap and frontal craniotomy [2] } \\
\text { - Transnasal } 70 \text { deg. endoscopic technique (large extension to frontal lobes) combined with open } \\
\text { rhinoplasty technique [17] }\end{array}$ \\
\hline
\end{tabular}

complications [34]. Although almost 40 years have passed since this publication, the basic assumptions of NDSC treatment rely on a radical excision using minimally invasive methods. Table II presents a summary of the surgical methods used for NDSC treatment over the past 20 years, depending on the lesion extension.

Minimally invasive technique such as open rhinoplasty alone or combined with additional local skin excision of the cyst is an optimal approach for removing NDSC used by many authors with achievement of favourable results, both aesthetically and functionally [10-12, 22, 35]. According to the information presented in Table II, this technique has been widely used for removing NDSC 5 with both an extracranial [2] and intracranial extradural extension [36, 37]. To maximize the vision of the operation field, some authors have also used endoscopes [2, 9, 12]. For NDSCs with an extracranial and additional intraosseous extension, Miller et al. and Livingstone et al. used an endoscopic-assisted open rhinoplasty technique to promote better visualization of the entire NDSC sinus tract, similar to the method used in our case $[2,9]$.
An additional elliptical skin incision is necessary for complete NDSC removal in cases involving opening of the skin of the NDSC sinus tract, which is in accordance with the method used to treat our patient [2, 16, 17, 27, 29]. For smaller lesions, resection using only this method is possible [11, 32]. Moreover, transnasal endoscopic approaches without any skin interference are reserved only for select cases of NDSC without skin involvement, limited to the intranasal space, with or without intracranial involvement [13]. A bicoronal flap and frontal craniotomy is an invasive surgical technique typically used by head and neck surgeons in cooperation with neurosurgeons [13, 24, 29].

Minimally invasive techniques imply a decreased risk of: cerebral damage with neurological deficits; CSF leakage; and olfactory nerve destruction with anosmia [38]. On the other hand, invasive techniques (e.g., craniotomy) are currently indicated less frequently, but continue to be used for very specific cases of NDSC treatment (i.e., extensive intracranial extensions of NDSC) [2]. However, the surgeon's experience is one of the main factors in determining the choice of technique [24, 39]. 
Although there are some proposals of dermoid cyst classifications available in the literature, none refer to dermoid cysts with a frontal sinus extension. In Tables III-V we have compiled all of the dermoid cyst classifications presented and published in the literature over the past 80 years. Table III presents the NDSC classifications, Table IV details the classifications of dermoid cysts of the head and neck region, and Table $V$ lists the dermoid cysts of orbit classifications [3, 23, 24, 29, 39-45].

In Figure 4, we present a new classification for dermoid cysts that affect the frontal sinus, depend-

Table III. Previous NDSC classifications

\begin{tabular}{|c|c|c|c|c|c|}
\hline Study & Year & Study design & Study group & Clinical endpoints & Proposed division \\
\hline $\begin{array}{l}\text { Musebeck, } \\
\text { Niedzielski } \\
{[8]}\end{array}$ & $\begin{array}{l}1968 \\
2004\end{array}$ & $\begin{array}{l}\text { Retrospective } \\
\text { case series }\end{array}$ & $\begin{array}{l}5 \text { paediatric } \\
\text { patients }\end{array}$ & $\begin{array}{l}\text { - } C T \text { and MRI radiologic } \\
\text { evidence of dermoid } \\
\text { cyst }\end{array}$ & $\begin{array}{l}\text { 1. Upper cysts localized between nasal } \\
\text { bones in the perpendicular plate of } \\
\text { the ethmoid bone } \\
\text { 2. Middle cysts localized in the quadran- } \\
\text { gular cartilage of nasal septum } \\
\text { 3. Lower cysts localized in the inferior or } \\
\text { membranous part of nasal septum }\end{array}$ \\
\hline Bradley [42] & 1983 & $\begin{array}{c}\text { Retrospective } \\
\text { case series }\end{array}$ & $\begin{array}{c}74 \text { paediatric } \\
\text { patients }\end{array}$ & $\begin{array}{l}\text { - Evidence of clinical } \\
\text { recurrence } \\
\text { - The location and der- } \\
\text { mal signs are no guide } \\
\text { to the degree of tissue } \\
\text { penetration of a nasal } \\
\text { dermoid }\end{array}$ & $\begin{array}{l}\text { 1. Simple (involving skin only) } \\
\text { 2. Complex (with deeper tissues) } \\
\text { - Nasal bones } \\
\text { - Nasal cartilage } \\
\text { - Septal cartilage } \\
\text { - Cribriform plate } \\
\text { - Ethmoidal air cells }\end{array}$ \\
\hline Ortlip [29] & 2015 & $\begin{array}{l}\text { Retrospective } \\
\text { case series }\end{array}$ & $\begin{array}{l}4 \text { paediatric } \\
\text { patients }\end{array}$ & $\begin{array}{l}\text { - CT and MRI evidence } \\
\text { of dermoid cyst } \\
\text { - Vertical midline } \\
\text { incision with modi- } \\
\text { fications to remove } \\
\text { dermoid cyst without } \\
\text { intracranial extension }\end{array}$ & $\begin{array}{l}\text { 1. Supratip extending through the up- } \\
\text { per lateral cartilages to the cartilagi- } \\
\text { nous septum } \\
\text { 2. Upper dorsum and subcutaneous } \\
\text { tissue } \\
\text { 3. Tip and supratip extending deep to } \\
\text { the nasal bones with involvement of } \\
\text { the anterior cranial fossae and dura } \\
\text { 4. Nasal tip extending deep to the level } \\
\text { of the rhinion and involving the upper } \\
\text { lateral cartilages and below the left } \\
\text { medial canthus }\end{array}$ \\
\hline Hartley [3] & 2015 & $\begin{array}{l}\text { Retrospective } \\
\text { case series }\end{array}$ & $\begin{array}{l}103 \text { paediat- } \\
\text { ric patients }\end{array}$ & $\begin{array}{l}\text { - CT and MRI evidence } \\
\text { of dermoid cyst } \\
\text { - Classification and } \\
\text { surgical management } \\
\text { according to the depth } \\
\text { of the dermoid cyst }\end{array}$ & $\begin{array}{l}\text { 1. Superficial lesions } \\
\text { 2. Intra-osseous lesions extend to the } \\
\text { nasal and frontal bones } \\
\text { 3. Intracranial extradural lesions } \\
\text { 4. Intracranial intradural lesions }\end{array}$ \\
\hline Miller [2] & 2019 & $\begin{array}{l}\text { Literature } \\
\text { review }\end{array}$ & $\begin{array}{l}\text { No informa- } \\
\text { tion }\end{array}$ & $\begin{array}{l}\text { - Early surgical removal } \\
\text { prevents local infection } \\
\text { of dermoid cyst and } \\
\text { further complication } \\
\text { - CT and MRI evidence } \\
\text { of dermoid cyst } \\
\text { - Surgical management } \\
\text { based on location and } \\
\text { intracranial extension }\end{array}$ & $\begin{array}{l}\text { 1. An isolated pit, with no associated } \\
\text { mass, located at the bony-cartilagi- } \\
\text { nous junction } \\
\text { 2. A protrusion at the nasal tip with pit } \\
\text { present along nasal dorsum between } \\
\text { the bony cartilaginous junction and } \\
\text { nasal tip } \\
\text { 3. A midline pit with or without a mass, } \\
\text { as well as pits overlying the lateral } \\
\text { nasal bones at the level of the medial } \\
\text { canthi } \\
\text { 4. Any of the above with large intracra- } \\
\text { nial component }\end{array}$ \\
\hline
\end{tabular}


Table IV. Previous classifications of dermoid cysts affecting the head and neck region

\begin{tabular}{|c|c|c|c|c|c|}
\hline Study & Year & Study design & Study group & Clinical endpoints & Proposed division \\
\hline New [43] & 1937 & $\begin{array}{l}\text { Retrospective } \\
\text { case series }\end{array}$ & No data & $\begin{array}{l}\text { - Higher rate of deep } \\
\text { subgroup of dermoid } \\
\text { cysts and periorbital } \\
\text { region of this lesion in } \\
\text { adult patients } \\
\text { - CT and MRI evidence } \\
\text { of dermoid cyst }\end{array}$ & $\begin{array}{l}\text { 1. Periorbital region } \\
\text { 2. Nasal region } \\
\text { 3. Submental region } \\
\text { 4. Midventral and mid-dorsal fusion } \\
\text { area of the suprasternal, thyroidal, } \\
\text { and suboccipital region }\end{array}$ \\
\hline Pryor [23] & 2005 & $\begin{array}{l}\text { Retrospective } \\
\text { case series }\end{array}$ & $\begin{array}{l}49 \text { paediatric } \\
\text { patients }\end{array}$ & $\begin{array}{l}\text { - CT and MRI evidence } \\
\text { of dermoid cyst } \\
\text { - Local changes of der- } \\
\text { moid cyst } \\
\text { - Histopathological con- } \\
\text { firmation is crucial }\end{array}$ & $\begin{array}{l}\text { 1. Cysts develop in the periorbital re- } \\
\text { gion and appear along the naso-optic } \\
\text { groove between the maxillary and } \\
\text { mandibular processes during embry- } \\
\text { onal closure } \\
\text { 2. Cysts develop over the dorsum of the } \\
\text { nose and are thought to develop during } \\
\text { ossification of the frontonasal plate } \\
\text { 3. Cysts are found in the submental re- } \\
\text { gion, the floor of the mouth, and the } \\
\text { region of fusion of the first and sec- } \\
\text { ond branchial arches in the midline } \\
\text { 4. Cysts are formed at the midventral } \\
\text { and mid-dorsal fusion in the su- } \\
\text { prasternal, thyroidal, and suboccipital } \\
\text { regions }\end{array}$ \\
\hline $\begin{array}{l}\text { Al-Khateeb } \\
\text { [6] }\end{array}$ & 2009 & $\begin{array}{l}\text { Retrospective } \\
\text { case series }\end{array}$ & $\begin{array}{c}109 \text { adult and } \\
\text { paediatric } \\
\text { patients }\end{array}$ & $\begin{array}{l}\text { - Histopathological con- } \\
\text { firmation is crucial }\end{array}$ & $\begin{array}{l}\text { 1. Periauricular area } \\
\text { 2. Cheek } \\
\text { 3. Neck } \\
\text { 4. Nasal complex } \\
\text { 5. Periorbital } \\
\text { 6. Scalp }\end{array}$ \\
\hline Prior [39] & 2018 & $\begin{array}{l}\text { Retrospective } \\
\text { case series }\end{array}$ & $\begin{array}{l}234 \text { adult } \\
\text { and paediat- } \\
\text { ric patients }\end{array}$ & $\begin{array}{l}\text { - Early surgical removal } \\
\text { prevents local infection } \\
\text { of dermoid cyst and } \\
\text { further complication } \\
\text { - USG and CT evidence } \\
\text { of dermoid cyst } \\
\text { - Differentiation } \\
\text { dermoid cyst from } \\
\text { epidermoid cyst } \\
\text { - Association between } \\
\text { frontotemporal loca- } \\
\text { tion and bone erosion }\end{array}$ & $\begin{array}{l}\text { 1. Frontal } \\
\text { 2. Occipital } \\
\text { 3. Supraorbital } \\
\text { 4. Retroauricular } \\
\text { 5. Parietal } \\
\text { 6. Pterional } \\
\text { 7. Glabellar } \\
\text { 8. Bregmatic } \\
\text { 9. Temporal } \\
\text { 10. Lambdoidal } \\
\text { 11. Orbital canthus }\end{array}$ \\
\hline Choi [5] & 2018 & $\begin{array}{l}\text { Retrospective } \\
\text { case series }\end{array}$ & $\begin{array}{c}32 \text { adult and } \\
\text { paediatric } \\
\text { patients }\end{array}$ & $\begin{array}{l}\text { - } \mathrm{CT}, \mathrm{MRI} \text {, and USG evi- } \\
\text { dence of dermoid cyst } \\
\text { - Direct approach is } \\
\text { preferable } \\
\text { - Higher rate of deep } \\
\text { subgroup of dermoid } \\
\text { cysts and periorbital } \\
\text { region of this lesion in } \\
\text { adult patients }\end{array}$ & $\begin{array}{l}\text { I. Location: } \\
\text { 1. Periorbital region } \\
\text { - Medial brow } \\
\text { - Lateral brow } \\
\text { 2. Ear } \\
\text { - Preauricular } \\
\text { - Retroauricular } \\
\text { 3. Nose } \\
\text { - Nasal dorsum } \\
\text { 4. Scalp } \\
\text { - Occipital } \\
\text { 5. Others } \\
\text { - Chin } \\
\text { - Cheek } \\
\text { II. Depth of the lesion: } \\
\text { 1. Subcutaneous layer } \\
\text { 2. Muscular layer } \\
\text { 3. Periosteum (intact, invasion) }\end{array}$ \\
\hline
\end{tabular}


Table V. Previous classifications of dermoid cysts affecting the orbit

\begin{tabular}{|c|c|c|c|c|c|}
\hline Study & Year & Study design & Study group & Clinical endpoint & Proposed division \\
\hline Cavazza [24] & 2011 & $\begin{array}{c}\text { Retrospective } \\
\text { case series }\end{array}$ & $\begin{array}{c}30 \text { paediatric } \\
\text { patients }\end{array}$ & $\begin{array}{l}\text { - } C T \text { and MRI evidence of } \\
\text { dermoid cyst } \\
\text { - Depth of the lesion } \\
\text { - A- and B-scan echog- } \\
\text { raphy evidence of } \\
\text { dermoid cyst } \\
\text { - Recurrence }\end{array}$ & $\begin{array}{l}\text { 1. An easily palpable mass that pres- } \\
\text { ents like a simple lesion anterior to } \\
\text { the orbital septum, exophytic } \\
\text { 2. A partially palpable or non-palpable } \\
\text { mass that grows posterior to the } \\
\text { septum, endophytic }\end{array}$ \\
\hline $\begin{array}{l}\text { Elbakary and } \\
\text { Eldesouky } \\
{[44]}\end{array}$ & 2016 & $\begin{array}{c}\text { Retrospective } \\
\text { case series }\end{array}$ & $\begin{array}{l}153 \text { adult } \\
\text { and paediat- } \\
\text { ric patients }\end{array}$ & $\begin{array}{l}\text { - } \text { CT evidence of dermoid } \\
\text { cyst } \\
\text { - The surgical method } \\
\text { depended on the depth } \\
\text { of the lesion } \\
\text { - Recurrence }\end{array}$ & $\begin{array}{l}\text { 1. Superficial dermoid cysts, either } \\
\text { lateral or medial, extending outside } \\
\text { (exophytic) or inside the orbital rim } \\
\text { or inside (endophytic) the orbital rim } \\
\text { 2. Deep dermoid cysts, which were } \\
\text { classified according to their site } \\
\text { into medial, lateral, superolateral, } \\
\text { retrobulbar, and inferior }\end{array}$ \\
\hline
\end{tabular}

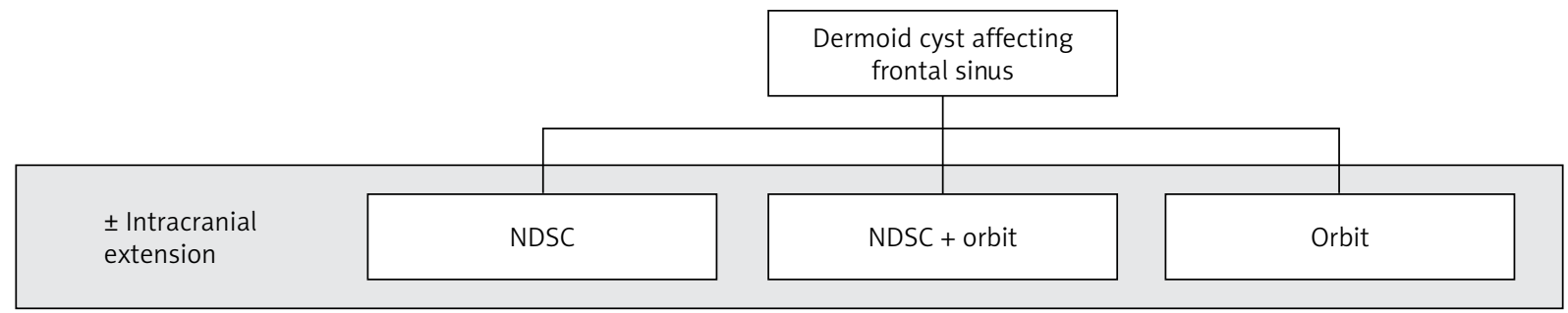

Figure 4. New classification of dermoid cysts affecting the frontal sinus depending on the involvement of both the external nose and orbit

ing on involvement of both the external nose and orbit with or without intracranial extension.

\section{Conclusions}

Dermoid cysts affecting the frontal sinus are rare lesions that may mimic complications of sinusitis. Due to their development in the frontal sinus, these lesions are more common in either older children or adults. Therefore, diagnostic CT and $M R I$ are mandatory. The recommended treatment involves a minimally invasive combined double approach using endoscopic-assisted open rhinoplasty with simultaneous ESS as the method of choice for treating NDSCs that affect the frontal sinus. This approach allows for a complete resection of the lesion while simultaneously maintaining aesthetic value for the patient. Furthermore, we present a review of the dermoid cyst classifications, surgical techniques for nasal dermoid cyst removal, and a new classification for dermoid cysts that affect the frontal sinus.

\section{Conflict of interest}

The authors declare no conflict of interest.

\section{References}

1. Charrier JB, Rouillon I, Roger G, et al. Craniofacial dermoids: an embryological theory unifying nasal dermoid sinus cysts. Cleft Palate Craniofac J 2005; 42: 51-7.

2. Miller C, Manning S, Bly R. Surgical management of nasal dermoid lesions. Operative Techniques in Otolaryngology 2019; 30: 16-21.

3. Hartley BE, Eze N, Trozzi M, et al. Nasal dermoids in children: a proposal for a new classification based on 103 cases at Great Ormond Street Hospital. Int J Pediatr Otorhinolaryngol 2015; 79: 18-22.

4. Post G, McMains KC, Kountakis SE. Adult nasal dermoid sinus cyst. Am J Otolaryngol 2005; 26: 403-5.

5. Choi JS, Bae YC, Lee JW, et al. Dermoid cysts: epidemiology and diagnostic approach based on clinical experiences. Arch Plast Surg 2018; 45: 512-6.

6. Al-Khateeb TH, Al-Masri NM, Al-Zoubi F. Cutaneous cysts of the head and neck. J Oral Maxillofac Surg 2009; 67: 52-7.

7. Golden BA, Zide MF. Cutaneous cysts of the head and neck. J Oral Maxillofac Surg 2005; 63: 1613-9. 
8. Niedzielski A, Kotowski M, Niedzielska G. Congenital cysts and fistulas of the dorsum of the nose. Otolaryngologia 2004; 3: 166-9.

9. Livingstone DM, Brookes J, Yunker WK. Endoscope-assisted nasal dermoid excision with an open rhinoplasty approach. Int J Pediatr Otorhinolaryngol 2018; 109: 101-3.

10. Hanikeri M, Waterhouse N, Kirkpatrick N, et al. The management of midline transcranial nasal dermoid sinus cysts. $\mathrm{Br}$ J Plast Surg 2005; 58: 1043-50.

11. Winterton RI, Wilks DJ, Chumas PD, et al. Surgical correction of midline nasal dermoid sinus cysts. J Craniofac Surg 2010; 21: 295-300.

12. Herrington H, Adil E, Moritz E, et al. Update on current evaluation and management of pediatric nasal dermoid. Laryngoscope 2016; 126: 2151-60.

13. Blake WE, Chow CW, Holmes AD, et al. Nasal dermoid sinus cysts: a retrospective review and discussion of investigation and management. Ann Plast Surg 2006; 57: 535-40.

14. Nelakanti RV, Kooreman NG,Wu JC. Teratoma formation: a tool for monitoring pluripotency in stem cell research. Curr Protoc Stem Cell Biol 2016; 32: 4A.8.1-17.

15. Uglietta JP, Boyko OB, Rippe DJ, et al. Intracerebral extension of nasal dermoid cyst: CT apperance. J Comput Assist Tomogr 1989; 13: 1061-4.

16. Lee DH, Yoon TM, Lee JK, et al. Dermoid cyst of nasal septum in an adult patient. A case report. Medicine 2018; 97: e13028.

17. Schuster D, Riley KO, Cure JK, et al. Endoscopic resection of intracranial dermoid cysts. J Laryngol Otol 2011; 125: 423-7.

18. Opsomer D, Allaeys T, Alderweireldt AS, et al. Intracranial complications of midline nasal dermoid cysts. Acta Chir Belg 2017; 119: $125-8$

19. Pham NS, Dublin AB, Strong EB. Dermoid cyst of the orbit and frontal sinus: a case report. Skull Base 2010; 20: 275-8.

20. Splendiani A, Bruno F, Mariani S, et al. A rare localization of pure dermoid cyst in the frontal bone. Neuroradiol J 2016; 29 130-3.

21. Patnaik A, Mishra SS, Das S, et al. Giant intradiploic dermoid cyst of the frontal bone with involvement of frontal sinus in an elderly patient. Neurology India 2012; 60: 542-3.

22. Gupta R, Gupta A, Budhiraja G, et al. Nasal dermoid sinus cyst expanding into frontal sinus: a rare presentation. Clin Rhinol An Int J 2012; 5: 123-6.

23. Pryor SG, Lewis JE, Weaver AL, et al. Pediatric dermoid cysts of the head and neck. Otolaryngol Head Neck Surg 2005; 132: 938-42.

24. Cavazza S, Laffi GL, Lodi L, et al. Orbital dermoid cyst of childhood: clinical pathologic findings, classification and management. Int Ophthalmol 2011; 31: 93-7.

25. Posnick JC, Bortoluzzi P, Armstrong DC. Nasal dermoid sinus cysts: an unusual presentation, computed tomographic scan findings, and surgical results. Ann Plast Surg 1994; 32: 519-23.

26. Edmonds LD, Ahluwalia JS, Fortman BJ, et al. Infected dermoid sinus tract mimicking recurrent sinusitis in an adolescent male. Curr Probl Diagn Radiol 2007; 36: 43-7.

27. Rahbar R, Shah P, Mulliken JB, et al. The presentation and management of nasal dermoid: a 30-year experience. Arch Otolaryngol Head Neck Surg 2003; 129: 464-71.
28. Volck AC, Suárez GA,Tasman AJ. Management of congenital midline nasofrontal masses: case report and review of literature. Case Rep Otolaryngol 2015; 2015: 159647.

29. Ortlip T, Ambro BT, Pereira KD. Midline approach to pediatric nasofrontal dermoid cysts. JAMA Otolaryngol Head Neck Surg 2015; 141: 174-7.

30. Zhang L, Hu C, Sun Z, et al. Correlation of tissue eosinophil count and chemosensory functions in patients with chronic rhinosinusitis with nasal polyps after endoscopic sinus surgery. Eur Arch Otorhinolaryngol 2019; 276: 1987-94.

31. Moore K, Ross A. Frontal sinus development and juvenile age estimation. Anat Rec 2017; 300: 1609-17.

32. Ray CN, Betteridge BC, Demke JC. Infected nasal dermoid cyst/ sinus tract presenting with bilateral subperiosteal supraorbital abscesses: the midline nasal tuft of hair, an overlooked finding. Ophthalmic Plast Reconstr Surg 2018; 34: e31-4.

33. Torske KR, Benson GS, Warnock G. Dermoid cyst of the maxillary sinus. Ann Diagn Pathol 2001; 5: 172-6.

34. Pollock RA. Surgical approaches to the nasal dermoid cyst. Ann Plast Surg 1983; 10: 498-501.

35. Re M, Tarchini P, Macrì G, et al. Endonasal endoscopic approach for intracranial nasal dermoid sinus cysts in children. Int J Pediatr Otorhinolaryngol 2012; 76: 1217-22.

36. Locke R, Kubba H. The external rhinoplasty approach for congenital nasal lesions in children. Int J Pediatr Otorhinolaryngol 2011; 75: 337-41.

37. Rohrich RJ, Lowe JB,Schwartz MR. The role of open rhinoplasty in the management of nasal dermoid cysts. Plast Reconstr Surg 1999; 104: 1459-66.

38. Seidel DU, Sesterhenn AM. Intracranial nasal dermoid sinus cyst: transnasal endoscopic resection by open rhinoplasty approach, with intraoperative video. J Craniofac Surg 2016; 27: 2110-2.

39. Prior A, Anania P, Pacetti M, et al. Dermoid and epidermoid cysts of scalp: case series of 234 consecutive patients. World Neurosurg 2018; 120: 119-24.

40. Loke DK, Woolford TJ. Open septorhinoplasty approach for the excision of a dermoid cyst and sinus with primary dorsal reconstruction. J Laryngol Otol 2001; 115: 657-9.

41. Weiss DD, Robson CD, Mulliken JB. Transnasal endoscopic excision of midline nasal dermoid from the anterior cranial base. Plast Reconstr Surg 1998; 102: 2119-23.

42. Bradley PJ. The complex nasal dermoid. Head Neck Surg 1983; 5: 469-73.

43. New GB, Erich JB. Dermoid cysts of the head and neck. Surg Gynecol Obstet 1937; 65: 48-55.

44. Eldesouky MA, Elbakary MA. Orbital Dermoid cyst: classification and its impact on surgical management. Semin Ophthalmol 2018; 33: 170-4.

45. Saettele M, Alexander A, Markovich B, et al. Congenital midline nasofrontal masses. Pediatr Radiol 2012; 42: 1119-25.

Received: 9.01.2020, accepted: 10.02.2020 